\title{
Evaluation of a dynamic simulation model for milk production systems ${ }^{1}$
}

\section{Daniel de Noronha Figueiredo Vieira da Cunha ${ }^{2}$, José Carlos Pereira ${ }^{3}$, Oriel Fajardo de Campos ${ }^{4}$, José Luis Braga ${ }^{5}$, Fabyano Fonseca e Silva ${ }^{6}$, Janaina Azevedo Martuscello ${ }^{2}$}

${ }^{1}$ Financiado pelo CNPq e pela FAPEMIG

2 Pós-doutorando em Zootecnia - UFVIDepartamento de Zootecnia.

3 UFVIDepartamento de Zootecnia.

4 PESAGRO-RJ.

${ }^{5}$ UFV/Departamento de Informática.

${ }^{6}$ UFV/Departamento de Estatística.

\begin{abstract}
The objective of this study was to develop and to evaluate a dynamic simulation model, with stochastic components in order to assess milk production systems. The simulation model was developed by using STELLA 9.0, ZooCalc 1.0 and electronic data sheets. The physical structure of the herd was divided into 15 interlinked modules that represented categories or subdivisions of categories. Mathematical models obtained from the literature were used to simulate the body weight of growing and lactating animals and milk production and milk composition. Electronic data sheets were used to calculate the nutritional requirements and dietary balance. After cost minimization, each feed was evaluated by using ZooCalc 1.0. Some average responses of farm size, zootechnical and economic index, the change in the area used for corn silage production, the calving interval and age at first insemination were obtained to evaluate whether the simulation model was working consistently with the expected. To assess the capacity of the model to generate simulated values that approach reality, the degree of linear association was measured between the values generated by the model and the values observed in practice. Sensitivity analyses showed that the values produced by the simulation model were in agreement with the expected results, in response to changes in the area of corn crop used for corn silage production, the calving interval and the age at first insemination. There was correlation between the values generated by the simulation model and the values observed in practice and the degree of linear association for the variables could be considered high.
\end{abstract}

Key Words: dairy cattle, modeling

\section{Avaliação de modelo dinâmico de simulação de sistemas de produção de leite}

RESUMO - Objetivou-se desenvolver e avaliar um modelo dinâmico de simulação com componentes estocásticos para avaliação de sistemas de produção de leite. O modelo de simulação foi desenvolvido utilizando-se os programas STELLA 9.0, ZooCalc 1.0 e planilhas eletrônicas. A estrutura física do rebanho foi dividida em 15 módulos interligados, que representam categorias ou subdivisões de categorias. Para simulação do peso corporal dos animais em crescimento e em lactação, assim como da produção e composição do leite, foram utilizados modelos matemáticos obtidos na literatura e, para cálculo de exigências nutricionais e balanceamento das dietas dos animais, planilhas eletrônicas. Após a redução do custo, cada ração foi avaliada pelo programa ZooCalc 1.0. Para avaliar se o modelo de simulação estaria funcionando de forma coerente com o esperado, foram obtidas as respostas médias de alguns indicadores de tamanho, de indicadores zootécnicos e econômicos e a variação da área utilizada para produção de milho para silagem, do intervalo de partos e da idade à primeira inseminação. Para avaliar a capacidade do modelo em gerar valores simulados que se aproximem da realidade, foi medido o grau de associação linear entre os valores gerados pelo modelo e observados em situação prática. As análises de sensibilidade comprovaram que os valores produzidos pelo modelo de simulação se comportam de acordo com o esperado, em resposta às variações da área utilizada para produção de milho para silagem, do intervalo de partos e da idade à primeira inseminação. Existe correlação entre os valores gerados pelo modelo de simulação e os observados na prática, e o grau de associação linear pode ser considerado elevado.

Palavras-chave: gado de leite, modelagem

\section{Introduction}

Simulation of production systems are important for farm management, because they can help administrators and extension technicians on decision taking, and for researches because they can be used to help to identify priority areas for scientific investigation, where there are knowledge gaps. Furthermore, simulation models can be 
used as teaching tools, to accelerate the learning process and experience gain by students.

The approach methods used by information technologies, computer simulation included, have a great impact on science, because they permit that it has a greater applied character and generates richness (Barbosa, 1986; Gavira, 2003).

This impact is due in part to the fast technical evolution of hardware and software resources, allied to the high availability of these resources on the market. Nevertheless, another factor that has contributed to the increase in computer simulation is the awareness that system components, when operated together, often perform differently from that observed when studied individually.

This relates to the necessary complementation of the analytical paradigm, that is based not only on the division of the object of study for the understanding of the isolated functioning of the more simple structures, which has been done in most researches in the animal science field, but also in later joining together to the knowledge acquired so that scientifically based generalizations can be made on the functioning of the whole.

One of the ways of constructing these generalizations consists in developing research on the impact of the use of technologies on the production systems. However, research of this nature requires a great quantity of physical and financial resources that, according to Brockington (1995), means that there is usually no possibility of repetition in space, but only in time. Thus, computer simulation applied to research on production systems is a promising alternative because in addition to being undemanding for physical and financial resources, it enables the study, in a short period of time, the use of combinations of diverse technologies in the most varied environmental conditions.

The objective of this study was to develop and assess a dynamic simulation system with stochastic components for bioeconomic assessment of milk production systems.

\section{Material and Methods}

The farm used as reference to construct and assess the simulation system is in the Cajuri municipality, Atlantic Rainforest region in Minas Gerais state, Brazil, and it was chosen for the study because of the great availability of data in its technical and economic records, in addition to the well-known tradition of dairy farming in the region. However, the simulation system can be easily adapted to other realities.

The farm area consists of 360 ha, of which 66.5 ha are under dairy farming. About 60 ha of these were used to produce corn for silage and the remainder were occupied by pastures and constructions. The herd was made up predominantly by animals of the Holstein breed and crossbred Holstein $\times$ Zebu (HZ), with a high degree of Holstein blood (from $15 / 16$ to $31 / 32 \mathrm{HZ}$ ). All the animals were reared in a dry-lot and they were corn silage and concentrate fed, except for those in the suckling phase, which received only concentrate and milk. The farm uses mechanized milking and artificial insemination. In 2007, the average number of lactating cows was 78.6 and the daily milk production was $1,861.2 \mathrm{~L}$ with a yield of $23.68 \mathrm{~L}$ per lactating cow/day. The calving interval was 14 months and the age at the first calving was 25.5 months.

The simulation system was developed with the integrated use of the STELLA 9.0 and ZooCalc 1.0 programs and the Micros oft Excel 2007 electronic spreadsheet. The dynamic structure of the herd, the mathematical prediction models of animal performance and the components related to the production costs were implemented by using the STELLA 9.0 program to simulate dynamic systems. The animal nutritional requirements and the minimum cost feeds were calculated according to the proposal in the NRC (2001) by spreadsheets elaborated in the Microsoft Excel 2007 program, using the SOLVER tool. The ZooCalc 1.0 (Cunha, 2010) program was used to assess the calculated feeds.

The physical structure of the herd was divided into 15 interlinked modules that represented categories or subdivisions of categories (Figure 1). The continuous arrows represent material flows between the modules, that is, they show the passage of animals from a previous module to a

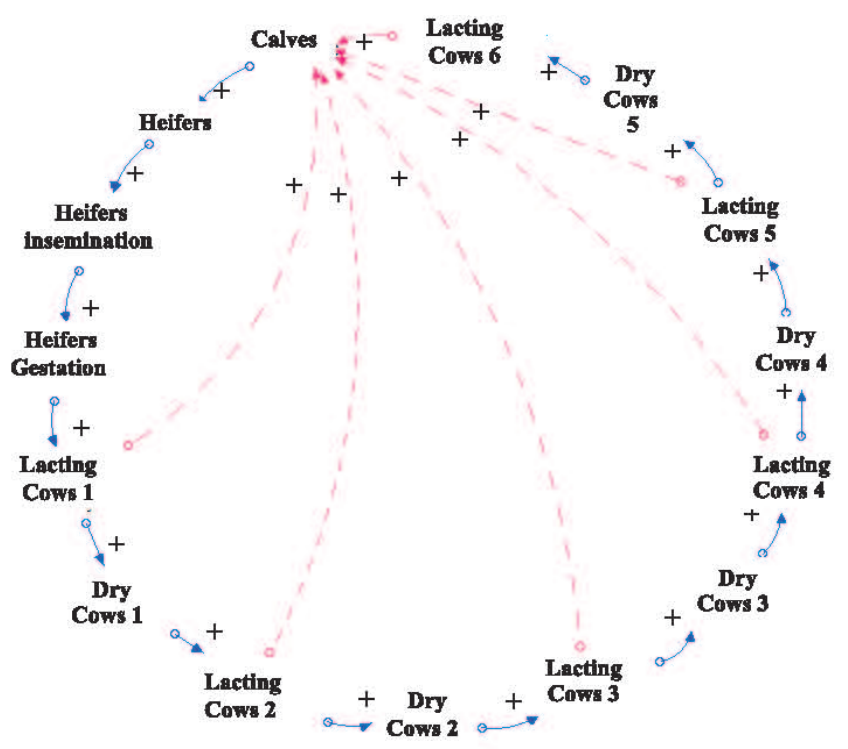

Figure 1 - Diagram of influence representing the division of the herd into 15 modules and the interlink among the modules (detailed explanation in the text). 
posterior module of the herd, while the broken arrows, which divide the lactating cow modules, represent information flows that determine the number of calving. The addition signs close to the arrows indicate positive influence of the number of animals in a module on the number of animals in the subsequent module, therefore the positive influence of the number of lactating cows on the number of calving. The information flows generated from these six lactating cow modules provided six positive feedback loop structures that re-feed the system so, if there were no control structures of the number of animals, the herd would expand indefinitely.

The proposed model self-regulates the herd size by animal purchase and sale. If the availability of forage produced $(F A v)$ is lower than the demand for forage (FDem), the number of animals sold would increase until $F A v=$ $F D e m$. Similarly, when $F A v>F D e m$, the number of animals purchased would increase until $F A v=F D e m$.

It was made a diagram representing, in general terms, three months of the simulated physical structure of one of the herd categories (Figure2). Themoduleswere subdivided into months, so that in each module, for each month, there was an accumulator variable (stock) that stored a determined quantity of animals in a specific category. Flows of entry, exit and promotion update the value of each stock at each interaction that corresponds to the simulated time interval of one month. Generally, the entry flows were flows of purchase or birth of animals, exit flows may represent death or sale of animals and promotion flows represent the passage of an imals from one age or months of a previous productive life to a posterior productive life, within the production system. Detailed information on the flow diagrams used to construct the simulation module can be obtained in Cunha
(2008) and on the symbology meaning used in the flow diagramsin Guimarães(2007).

The dynamic of the generalized physical structure of one of the herd categories (Figure 2) can be mathematically expressed as $C m l(t)=C m l(t-d t)+(f x E C+f x C p C m l-$ $f x C m I m 2-f x M t C m 1-f x V d C m I) * d t$

$\mathrm{Cm} 2(\mathrm{t})=\mathrm{Cm} 2(\mathrm{t}-\mathrm{dt})+(\mathrm{fxCm} 1 \mathrm{~m} 2+\mathrm{fxCpCm} 2-\mathrm{fxCm} 2 \mathrm{~m} 3$ $-\mathrm{fxMtCm} 2-\mathrm{fxVdCm} 2)^{*} \mathrm{dt}$

$C m 3(t)=C m 3(t-d t)+(f x C m 2 m 3+f x C p C m 3-$ $f x \mathrm{Cm} 3 m N-f x M t C m 3-f x V d C m 3) * d t$, where: $f x E C=$ entry flow of animals to category $\mathrm{C} ; \mathrm{Cm} 1, \mathrm{Cm} 2$ and $C m 3=$ number of animals in category $C$, in the months $m 1, m 2$ e $m 3 ; f x C p C m 1, f x C p C m 2, f x C p C m 3=$ flows of animal purchase in the months $m 1, m 2$ and $m 3$ in category $C$; $f x V d C m 1, f x V d C m 2, f x V d C m 3=$ flows of animal sales in the months $m 1, m 2$ and $m 3$ of category $C$; fxMtCml, fxMt Cm2, fxMtCm3 = flows of animal death in the months $m 1, m 2$ and $m 3$ to category $C ; f x C m 1 m 2, f x C m 2 m 3$, $\mathrm{fxCm} 3 \mathrm{mN}=$ flow in promotion of animals from the first to the second month from the second to the third month and from the third to the n-th months of $\mathrm{t}$ category $C ; d t=$ time interval used in the simulation to update the value of the variables; $t=$ simulated real-time.

The Calfmoduleregisters animalsfrom one to 12 months of age and receives information generated by the entry of animals in the lactating cow module that determines the number of calving. TheHeifer module records animals from 13 months of age to the months prior to that in which they reach the minimum weight for first insemination. In the simulation module, there is no specific age at which the heifers are able for reproduction, so animals of any stock from the Heifer module can be transferred to the Heiferinsemination module, provided they have reached the

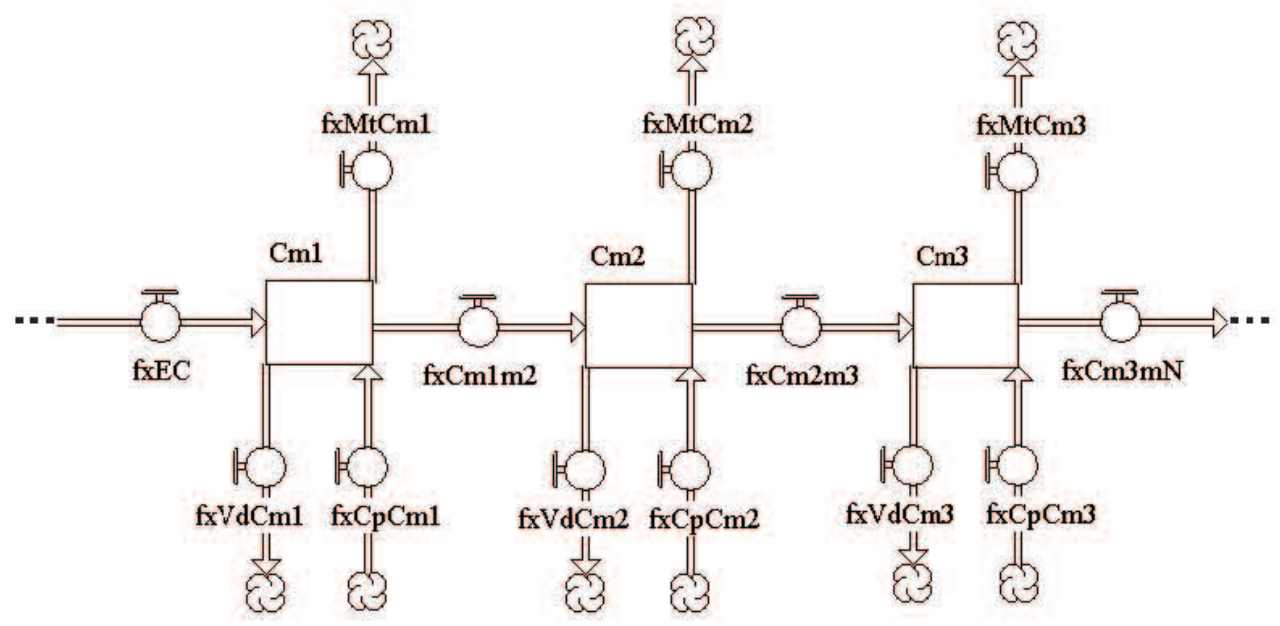

Figure 2 - Flow diagram representing, in general terms, three months of the simulated physical structure of one of the herd categ ories. 
minimum age for this. The determinants for the age at first insemination are the minimum weight established for the first insemination, the calf weight at birth and the growth rate of the animals. In the module, the minimum weight of $50 \%$ of the body weight at maturity was adopted for the first insemination.

The lactating cow category was subdivided into six modules that represented six lactating numbers. Each module of lactating cows is connected to the subsequent dry cow module, to which material is transfered. As a simplification, the module assumes that there are no cows with more than six lactation numbers and consequently, all the animals kept in the herd until the end of the sixth lactation number were then discarded.

The lactating cow module registers animals from the first month of lactation to month n of lactation, so that $n$ represents the average duration, in months, of the lactations of the animals in the herd. The dry cow module record animals from the first month to the $n$ month in the interval between the end of one lactation and the start of the subsequent lactation. In this case, $\mathrm{n}$ represents the value, in months, obtained from the difference between the average calving interval and the av erage duration of the lactations of the animals in the herd. More details on the simulated physical structure of the herd can be obtained in Cunha (2010).

The model by Lopezet al. (2000) was used to predict the body weight of the animals at birth to the age of the first insemination.

$$
y_{t}=\frac{a \cdot k^{c}+b \cdot t^{c}}{k^{c}+t^{c}}
$$

where: $y=$ body weight on day $t(\mathrm{~kg}) ; a=$ weight at birth $(\mathrm{kg})$; $b=$ weight at maturity $(\mathrm{kg}) ; c=$ parameter that determines the sigmoid shape of the curve; $k=$ age at which $50 \%$ of the body weight at maturity is reached.

The parameters of the model by Lopez et al. (2000) were fitted using the NLIN procedure of SAS, applied to 714 body weight data from 47 animals in the growing phase, from the farm used as reference to develop the simulation system.

Body weight gain of the heifers in gestation was calculated as the difference between weight at first insem ination and the weight at first calving, assumed to be $80 \%$ of the body weight at maturity.

The model by Rotz et al. (1999) was used to predict the body weight of the animals during lactation. Since there was no data for weight of lactating animals in the farm records, it was used the values of the parameters suggested by Rotz et al. (1999) for primiparous and multiparous separated.

$$
y_{t}=a \cdot\left(\frac{t}{7}+b\right)^{-c} \cdot e^{d \cdot\left(\frac{t}{7}+h\right)}
$$

where: $y=$ body weight on day $t$ of lactation; $a, b, c, d, h=$ module parameters.

The body weight gain of cows in the rest period was assumed as $0.8 \mathrm{~kg}$ per day for cows after the first lactation and $0.65 \mathrm{~kg}$ for cows after the other lactations.

The model by Dijkstra et al. (1997) was used to predict milk production per cow.

$$
y_{t}=a \cdot e^{b \cdot \frac{1-e^{-c \cdot t}}{c}-d \cdot t},
$$

where: $y=$ milk production on day $t$ of lactation (L/day); $a, b, c, d=$ module parameters.

The model by Dijkstra etal. (1997) was selected among eight lactation curve models because it presented the best fit for the milk production data of the animals in the farm, as reported in Cunha (2008). The module parameters were fitted for lactations of first, second and third or greater numbers using the NLIN procedure in SAS. Milk production per cow received stochastic treatment, assuming normal distribution with an $11.0 \%$ coefficient of variation. The variation used was based on the results obtained by Bernard et al. (2002) and Taylor \& Allen (2005).

The percentage of fat and protein in milk were predicted by using the models and parameters recommended in CNCPS 5.0 (Fox et al., 2003) for the Holstein breed.

$$
\begin{aligned}
& P G_{t}=a \cdot b \cdot\left(\frac{t+1}{7}\right)^{-c} \cdot e^{d \cdot\left(\frac{t+1}{7}\right)} \\
& P P_{t}=k \cdot j \cdot\left(\frac{t+1}{7}\right)^{-l} \cdot e^{m \cdot\left(\frac{t+1}{7}\right)},
\end{aligned}
$$

where: $P G=$ milk fat percentage at time $t$ of lactation; $P P=$ percentage of milk protein at time $t$ of lactation; $a, b$, $c, d, k, j, l, m=$ model parameters.

The nutritional requirem ents and dietary balance of the animals were calculated by using electronic spreadsheets elaborated according to the NRC (2001) equations. The cost of each feed was reduced with the help of the SOLVER tool in the Microsoft XL 2007. After reducing the cost, each feed was assessed using the ZooCalc 1.0 program (Cunha, 2010).

The composition data of the feeds used in this work were obtained from scientific articles, theses and 
dissertations and from the feed databank of the CNCPS 5.0 software. The feeds used to formulate the feed were corn silage, corn flour, wheat meal, soybean meal, corn gluten and urea and whole milk that was given $(4.0 \mathrm{~L} /$ day $)$ to calves up to two months of age.

All the production cost components were obtained from accountancy records of the company for the period from December 2006 to November 2007, and they were corrected by the IGP-DI of December 2007. Some production cost components are variable and so proportionality indexes were established from these costs, in relation to the number of animals in the herd, as reported in Ávila(2004).

The effective operational cost was calculated by considering the expenses with contracted labor, electricity, fuel, medication, hormones, artificial insemination material, milking material, machine maintenance, installation maintenance, non-annual forage maintenance, taxes, animal rates and feeding. The total operational cost was calculated by summing the effective operational cost to the expenses with family labor. The depreciation of machinery, installations, non-annual forages, reproducers and work animals was calculated according to Gomes (2000). The total production cost was calculated by adding the total operational cost to return on capital invested in land, installations, equipment and animals. For this, an interest rate of $0.6782 \%$ per month was considered, based on the av erage rate of interest of the saving account in 2007.

The gross margin of the activity was calculated by subtracting the effective operational cost from the total gross income and the net margin by the difference between total gross income and effective operational cost. The profit from the activity was estimated by the difference between total gross income and total production cost and the rate of return on capital investment was calculated by dividing the net margin by the value of the capital invested in installations, equipment, and animals. The return on capital investment was also calculated by considering the capital invested in land. The average production costs per liter of milk were calculated considering the proportionality between milk revenue and total income of the activity, as recommended by Gomes (2000). The milk prices used during the simulations were obtained from the series of monthly values received per liter of milk, from December 2006 to November 2007, present in the accountancy records of the company.

To evaluate whether the simulation model would work coherently as expected, the average responses were obtained from some farm size, zootechnical and economic indexes, considering the variation in the area used for corn production for silage $(50,55,60,65$ and $70 \mathrm{ha})$ and the calving interval $(12,13,14,15$ and 16 months $)$.

To carry out the sensitivity tests, the model was programmed, therefore in each scenario accessed, the herd remained stabilized during the simulation time ( 120 months). In all these simulations, the lactation period was considered to be 10 months. In the simulations for the sensitivity tests for variation in the planted area, the model was programmed for a 14 month calving interval. In the sensitivity tests for calving interval, the area used for corn crop for silage was fixed at 60 ha.

The capacity of the model to generate simulation values that were close to reality was assessed by measuring the degree of linear association among the values generated by the model and observed in the production system using the CORR procedure of SAS

The variables compared were total_number_of_animals, total_number_of_cows, number_of_lactating_cows and daily_milk_production.

The values observed were obtained from the farm monthly records from December 2006 to November 2007. As the farm expanded its activity during this period by increasing the number of animals, the module was programmed so that the herd was not stabilized and the number of animals increased proportionately to that observed in practice.

\section{Results and Discussion}

As the herds were stabilized, there was no tendency to increase or decrease milk production (Figure 3 ). Thus, the change in milk production within each fixed area for corn crop for silage refers exclusively to the random component of normal distribution of the stochastic variable.

The effect of area used for corn crop on milk production was clearly observed. This occurred because the simulation model regulates the herd size according to forage availability. This self-regulation is based on the assumption that there is no possibility of purchasing bulk feeds on the market, or that the purchase of these bulk feeds would not be economically desirable or even that the deficits of all bulk feeds could not be overcome, in part, by a greater supply of concentrate feeds. Although this supposition may not be absolutely correct, it becomes acceptable, starting from the concept that the simulation is a simplification of reality.

As it was foreseen, all the values of the preliminary indexes decreased in response to the decrease of the area used for corn crop (Table 1) as a direct consequence of the proper functioning of the simulation model.

Except for annual labor productivity and annual land productivity, all the zootechnical indexes were numerically 


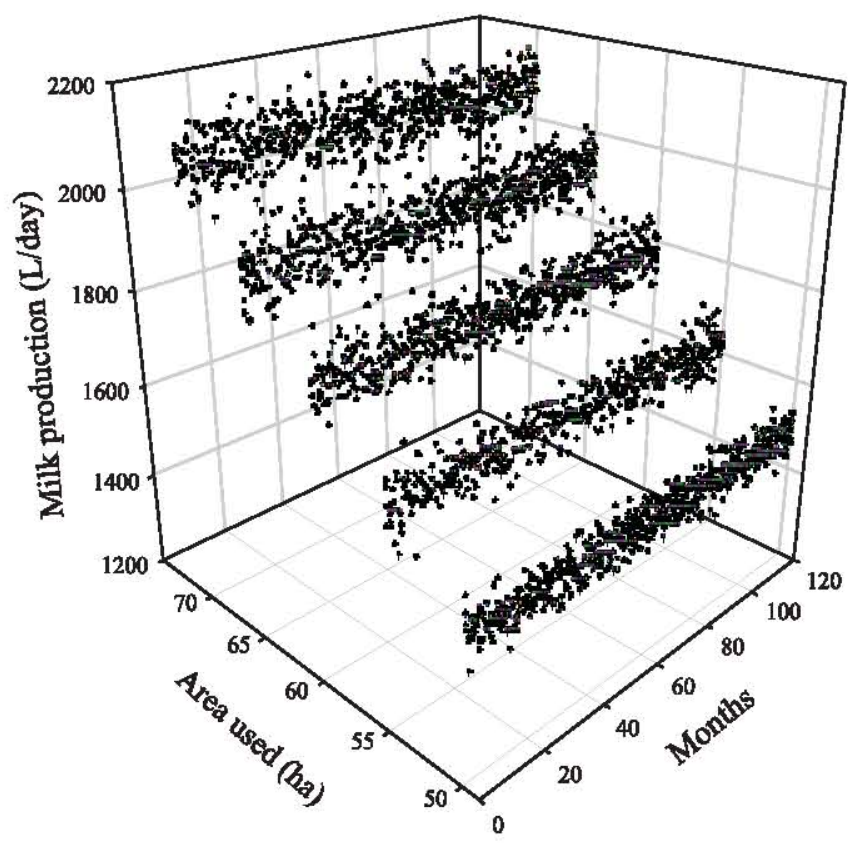

Figure 3 - Effect of area used for corn crop for silage on the simulated average daily milk production during 120 months.

insensitive to the change in the size of area used for corn crop that was expected, because the herd structure should not be altered by modifications in the size of area used for this activity. Although in the simulation model the number of man day ( $\mathrm{md}$ ) of the milker and assistant milker were considered proportional to the number of lactating cows and the number of temporary labor m an day was considered proportional to the number of animals in the herd, reduction in the annual labor productivity in response to decrease in the corn crop area may have been caused by the fact that family labor was considered constant. It was considered in this way because a businessman would have greater difficulty to fire a member of the family or to require the additional labor from a family member.

There was a small increase in annual land productivity resulting from the increase in the area used for corn crop for silage. As the zootechnical indexes and the herd structure were not altered, the increase was exclusively due to the fact that the areas not under corn crop, including constructions and roads, were considered constant because it would be difficult to use them for other activities.

The milk/concentrate ratio was very close to 3.00 , a widely recommended value as a management practice in Brazil. This attributed greater credibility to the simulation model by Ávila (2004) who, as a simplification, assumed that the quantity of concentrate fed to the lactating cows would be $1.0 \mathrm{~kg}$ as fed for each $3.0 \mathrm{~L}$ of milk produced. However, this ratio does not always assume this value because it depends on the type of bulk feed used, as demonstrated by Rennó et al. (2008a, b, c). A simplification of this nature may be more suitable if the influence of the type of bulk feed used was considered. This certainly would reduce the work of the researcher and make the model more agile probably without losing accuracy in the results. Another source of change for milk/concentrate ratio would be the milk solid contents, because the percentage of milk fat and protein alter the energy and protein requirements per liter of milk produced.

The simulated milk fat and protein contents were, respectively, $3.72 \%$ and $3.31 \%$. These results were close to the average values of $3.69 \%$ fat and $3.24 \%$ protein reported by Ribas et al. (2004), who analyzed 257,540 milk samples taken from expansion tanks in farms that use Holstein breed animals in the states of Paraná, São Paulo and Santa Catarina.

The values of the economic indexes of milk gross income and total gross income followed the change in the corn crop area, while the percentage of milk gross income in the total gross income was not altered. This occurred because the number of cows and heifers discarded also changed proportionately to the corn crop area.

Although the value of the total operational cost followed the increase in the area used for corn crop, the average effective operational cost of milk did not change. This performance is explained by the variable character of the effective operational cost components, for which, except for expenses and feeds, proportionality indexes were established according to the number of lactating cows or the total number of animals. The total operational cost and the total production cost also vary proportionately to the area used for corn crop. However, the total of the change in total operational cost and much of the change in total production cost were due to effective operational cost, because family labor, machine depreciation, installation, non-annual forage, work animals and the capital invested in machines and installations were considered constant. Because of the constant character of the depreciations, family labor, and capital invested in machines and installations, the mean total operational cost of the milk and the average total production cost of the milk decreased as the area used in the activity increased.

The positive gross margin values indicated that at least in the short term, considering all the fixed sizes for the area used for corn crop, the enterprise was economically viable. In all fixed areas, the positive net margin indicated that family labor was being paid, that the values of wear and obsolescence of the machinery, installation and non-annual 
Table 1 - Performance of the farm size, zootechnical and economic indexes in response to the change in the area used for corn crop for silage

\begin{tabular}{|c|c|c|c|c|c|c|}
\hline \multirow[t]{2}{*}{ Item } & \multirow[b]{2}{*}{ Unit } & \multicolumn{5}{|c|}{ Calving interval (month) } \\
\hline & & 12 & 13 & 14 & 15 & 16 \\
\hline \multicolumn{7}{|l|}{ Farm size indexes } \\
\hline Lactating cows & $\mathrm{n}$ & 84.96 & 81.18 & 77.88 & 74.85 & 72.04 \\
\hline Total cows & $\mathrm{n}$ & 97.64 & 99.35 & 101.13 & 102.78 & 104.30 \\
\hline Total calves/heifers & $\mathrm{n}$ & 101.18 & 96.68 & 92.75 & 89.14 & 85.79 \\
\hline Total animals & $\mathrm{n}$ & 198.82 & 196.03 & 193.89 & 191.92 & 190.09 \\
\hline Culled cows & n/year & 25.86 & 24.71 & 23.71 & 22.78 & 21.93 \\
\hline Discarded heifers & n/year & 22.57 & 21.56 & 20.69 & 19.88 & 19.13 \\
\hline Milk production & L/year & 712,089 & 680,406 & 652,803 & 627,352 & 603,811 \\
\hline Total concentrate ${ }^{1}$ & $\mathrm{~kg} /$ year & 299,033 & 286,058 & 280,195 & 274,789 & 269,789 \\
\hline Labor & $\mathrm{md} /$ year & 1,284 & 1,244 & 1,210 & 1,178 & 1,148 \\
\hline \multicolumn{7}{|l|}{ Zootechnical indexes } \\
\hline Milk production/lactating cow & $L /$ day & 22.99 & 22.99 & 22.99 & 22.99 & 22.99 \\
\hline Milk production/total of cows & $L /$ day & 20.00 & 18.78 & 17.70 & 16.74 & 15.87 \\
\hline Milk concentrate ratio ${ }^{2}$ & $\mathrm{~L} / \mathrm{kg}^{1}$ & 2.97 & 3.02 & 3.02 & 3.02 & 3.02 \\
\hline Productivity of concentrate 3 & $\mathrm{~L} / \mathrm{kg}$ & 2.38 & 2.38 & 2.33 & 2.28 & 2.24 \\
\hline Lactating cows to total cows ratio & $\mathrm{n} / \mathrm{n}$ & 0.8701 & 0.8171 & 0.7701 & 0.7282 & 0.6907 \\
\hline Lactating cows to total animals ratio & $n / n$ & 0.4273 & 0.4141 & 0.4017 & 0.3900 & 0.3790 \\
\hline Culled cow rate & $\mathrm{CC} / \mathrm{TC}$ & 0.2648 & 0.2487 & 0.2344 & 0.2217 & 0.2102 \\
\hline Calves and heifers discard rate & $\mathrm{DH} / \mathrm{TCH}$ & 0.2230 & 0.2230 & 0.2230 & 0.2230 & 0.2230 \\
\hline Annual labor productivity & $\mathrm{L} / \mathrm{md}$ & 554.35 & 546.67 & 539.49 & 532.49 & 525.67 \\
\hline Annual land productivity & L/ha & 10.789 & 10.309 & 9.890 & 9.505 & 9.148 \\
\hline \multicolumn{7}{|l|}{ Economic indexes } \\
\hline Milk gross income & $\mathrm{R} \$$ year & 504.549 & 482.212 & 462.649 & 444.612 & 427.928 \\
\hline Total gross income & $\mathrm{R} \$$ year & 589.085 & 562.987 & 540.147 & 519.088 & 499.609 \\
\hline (Milk gross income/total gross income) $\times 100$ & $\%$ & 85.6490 & 85.6510 & 85.6510 & 85.6510 & 85.6510 \\
\hline Effective operational cost & $\mathrm{R} \$ /$ year & 396,460 & 386,609 & 381,337 & 376,476 & 371,979 \\
\hline Total operational cost & $\mathrm{R} \$$ year & 472,500 & 462,650 & 457,378 & 452,517 & 448,020 \\
\hline Total cost & $\mathrm{R} \$$ year & 540,592 & 530,681 & 525,402 & 520,535 & 516,034 \\
\hline Effective operational cost of milk & $\mathrm{R} \$ / \mathrm{L}$ & 0.4769 & 0.4867 & 0.5003 & 0.5140 & 0.5277 \\
\hline Total operational cost of milk & $\mathrm{R} \$ / \mathrm{L}$ & 0.5683 & 0.5824 & 0.6001 & 0.6178 & 0.6355 \\
\hline Total mean cost of milk & $\mathrm{R} \$ / \mathrm{L}$ & 0.6502 & 0.6681 & 0.6894 & 0.7107 & 0.7320 \\
\hline Gross margin & $\mathrm{R} \$$ year & 192,625 & 176,377 & 158,809 & 142,612 & 127,630 \\
\hline Net margin & $\mathrm{R} \$$ year & 116,584 & 100,336 & 82,769 & 66,571 & 51,589 \\
\hline Profit & $\mathrm{R} \$$ year & 48,492 & 32,306 & 14,744 & $-1,447$ & $-16,424$ \\
\hline Return on capital ${ }^{4}$ & $\% /$ year & 17,5850 & 15,1540 & 12,5020 & 10,0560 & 7,7940 \\
\hline Return on capital ${ }^{5}$ & $\% /$ year & 13,9290 & 11,9990 & 9,8990 & 7,9620 & 6,1710 \\
\hline
\end{tabular}

$\mathrm{md}=$ man days; ${ }^{1}$ as fed; ${ }^{2} \mathrm{Concentrate}$ used per lactating cows; ${ }^{3} \mathrm{Concentrate}$ used per all he herd; ${ }^{4} \mathrm{Without}$ payment of the land factor; ${ }^{5} \mathrm{With}$ payment of the land factor.

forages were being replaced and that there was return on capital invested in the activity, but, when only 50 ha were allocated for corn crop for silage, the property operated at a loss.

The change of one hectare of the area used for corn crop for silage corresponded to the average change of approximately $10,880 \mathrm{~L}$ milk per year and $\mathrm{R} \$ 1,949.00$ annual income. The data generated showed that the condition of normal income would occur when the area used for corn crop for silage was somewhere between 50 and 55 ha. When the income is normal, the enterprise pays the capital invested at a rate equivalent to that of market interest, configuring a situation of equilibrium (Oliveira et al., 2007).

There was no tendency in any fixed calving interval to increase or decrease in milk production during the simulated months (Figure 4) and the change in average daily production among the months followed a random pattern, with normal distribution. Reduction was observed in average daily milk production with an increase in CI that was aligning with the expected.

Milk production increased about $4.2 \%$, on average, with the decrease in each month of CI (Table 2). Reduction in CI from 15 to 12 months resulted in a $17.5 \%$ increase in annual milk production. Oliveira et al. (1999) reported a very similar value when researching the income of milk producing farms in the region of Viçosa, Minas Gerais, Brazil and observed that the reduction in CI from 15 to 12 months corresponded to an approximate increase of $15 \%$ in milk production. Ávila (2004) observed increases of 3.4 and $3.9 \%$ in annual milk production in response to reduction in calving interval from 15 to 12 months. 


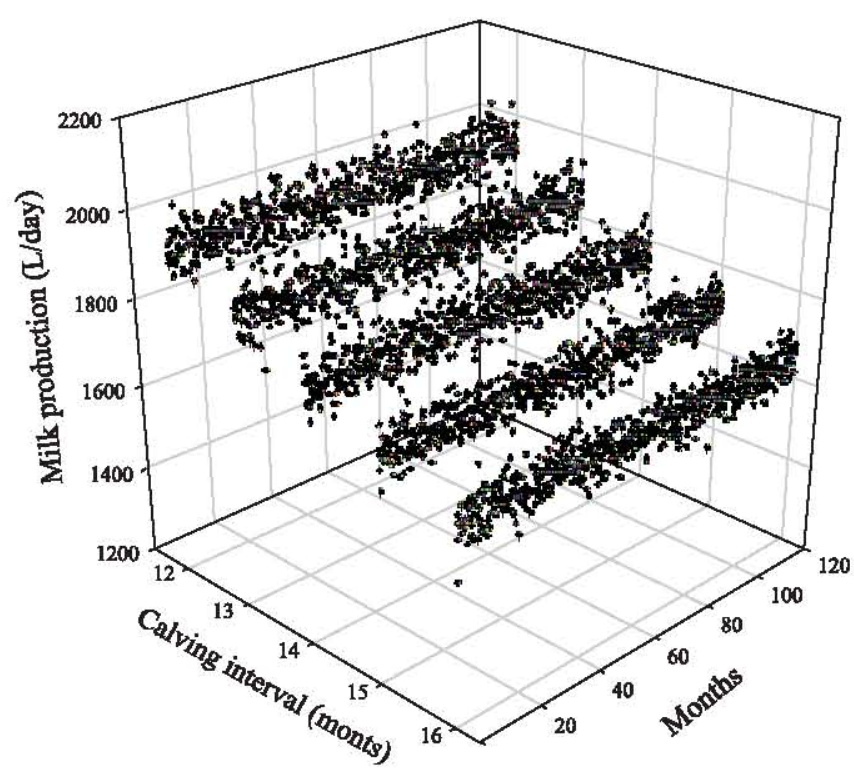

Figure 4 - Effect of calving interval on simulated average daily milk production during 120 months.
As calving interval increased, the number of lactating cows (LC) decreased while the total number of cows, and consequently the number of dry cows, increased. As a result, the ratio between the number of lactating cows and the total number of cows decreased in response to the increase in calvin interval, which was expected.

The total number of animals decreased with the increase in calving interval Under real conditions, this is expected, due to the small num ber of births. In the simulation model, another factor that contributed to the decrease in total number of animals with the increase in calving interval was the increase in the total number of cows, because the total number of animals is regulated by the ratio between forage demand and availability, and as dry cows and lactating cows are the categories that present greatest forage intake, greater total number of cows compared to the number of animals implies greater average forage intake per animal in the herd.

Table 2 - Performance of the farm size, zootechnical and economic indexes in response to the change in calving interval

\begin{tabular}{|c|c|c|c|c|c|c|}
\hline \multirow[t]{2}{*}{ Item } & \multirow[b]{2}{*}{ Unit } & \multicolumn{5}{|c|}{ Calving interval (month) } \\
\hline & & 12 & 13 & 14 & 15 & 16 \\
\hline \multicolumn{7}{|l|}{ Farm size indexes } \\
\hline Lactating cows & $\mathrm{n}$ & 84.96 & 81.18 & 77.88 & 74.85 & 72.04 \\
\hline Total cows & $\mathrm{n}$ & 97.64 & 99.35 & 101.13 & 102.78 & 104.30 \\
\hline Total calves/heifers & $\mathrm{n}$ & 101.18 & 96.68 & 92.75 & 89.14 & 85.79 \\
\hline Total animals & $\mathrm{n}$ & 198.82 & 196.03 & 193.89 & 191.92 & 190.09 \\
\hline Culled cows & n/year & 25.86 & 24.71 & 23.71 & 22.78 & 21.93 \\
\hline Discarded heifers & n/year & 22.57 & 21.56 & 20.69 & 19.88 & 19.13 \\
\hline Milk production & L/year & 712,089 & 680,406 & 652,803 & 627,352 & 603,811 \\
\hline Total concentrate ${ }^{1}$ & $\mathrm{~kg} /$ year & 299,033 & 286,058 & 280,195 & 274,789 & 269,789 \\
\hline Labor & $\mathrm{md} /$ year & 1,284 & 1,244 & 1,210 & 1,178 & 1,148 \\
\hline \multicolumn{7}{|l|}{ Zootechnical indexes } \\
\hline Milk production/lactating cow & $\mathrm{L} /$ day & 22.99 & 22.99 & 22.99 & 22.99 & 22.99 \\
\hline Milk production/Total of cows & $\mathrm{L} /$ day & 20.00 & 18.78 & 17.70 & 16.74 & 15.87 \\
\hline Milk concentrate ratio ${ }^{2}$ & $\mathrm{~L} / \mathrm{kg}^{1}$ & 2.97 & 3.02 & 3.02 & 3.02 & 3.02 \\
\hline Productivity of concentrate ${ }^{3}$ & $\mathrm{~L} / \mathrm{kg}$ & 2.38 & 2.38 & 2.33 & 2.28 & 2.24 \\
\hline Lactating cows to total cows ratio & $\mathrm{n} / \mathrm{n}$ & 0.8701 & 0.8171 & 0.7701 & 0.7282 & 0.6907 \\
\hline Lactating cows to total animals ratio & $\mathrm{n} / \mathrm{n}$ & 0.4273 & 0.4141 & 0.4017 & 0.3900 & 0.3790 \\
\hline Culled cow rate & $\mathrm{CC} / \mathrm{TC}$ & 0.2648 & 0.2487 & 0.2344 & 0.2217 & 0.2102 \\
\hline Calves and heifers discard rate & $\mathrm{DH} / \mathrm{TCH}$ & 0.2230 & 0.2230 & 0.2230 & 0.2230 & 0.2230 \\
\hline Annual labor productivity & $\mathrm{L} / \mathrm{md}$ & 554.35 & 546.67 & 539.49 & 532.49 & 525.67 \\
\hline Annual land productivity & $\mathrm{L} / \mathrm{ha}$ & 10.789 & 10.309 & 9.890 & 9.505 & 9.148 \\
\hline \multicolumn{7}{|l|}{ Economic indexes } \\
\hline Milk gross income & $\mathrm{R} \$ /$ year & 504.549 & 482.212 & 462.649 & 444.612 & 427.928 \\
\hline Total gross income & $\mathrm{R} \$ /$ year & 589.085 & 562.987 & 540.147 & 519.088 & 499.609 \\
\hline (Milk gross income/total gross income) $\times 100$ & $\%$ & 85.6490 & 85.6510 & 85.6510 & 85.6510 & 85.6510 \\
\hline Effective operational cost & $\mathrm{R} \$ /$ year & 396,460 & 386,609 & 381,337 & 376,476 & 371,979 \\
\hline Total operational cost & $\mathrm{R} \$ /$ year & 472,500 & 462,650 & 457,378 & 452,517 & 448,020 \\
\hline Total cost & $\mathrm{R} \$ /$ year & 540,592 & 530,681 & 525,402 & 520,535 & 516,034 \\
\hline Effective operational cost of milk & $\mathrm{R} \$ / \mathrm{L}$ & 0.4769 & 0.4867 & 0.5003 & 0.5140 & 0.5277 \\
\hline Total operational cost of milk & $\mathrm{R} \$ / \mathrm{L}$ & 0.5683 & 0.5824 & 0.6001 & 0.6178 & 0.6355 \\
\hline Total mean cost of milk & $\mathrm{R} \$ / \mathrm{L}$ & 0.6502 & 0.6681 & 0.6894 & 0.7107 & 0.7320 \\
\hline Gross margin & $\mathrm{R} \$ /$ year & 192,625 & 176,377 & 158,809 & 142,612 & 127,630 \\
\hline Net margin & $\mathrm{R} \$$ /year & 116,584 & 100,336 & 82,769 & 66,571 & 51,589 \\
\hline Profit & $\mathrm{R} \$ /$ year & 48,492 & 32,306 & 14,744 & $-1,447$ & $-16,424$ \\
\hline Return on capital ${ }^{4}$ & $\% /$ year & 17,5850 & 15,1540 & 12,5020 & 10,0560 & 7,7940 \\
\hline Return on capital ${ }^{5}$ & $\% /$ year & 13,9290 & 11,9990 & 9,8990 & 7,9620 & 6,1710 \\
\hline
\end{tabular}

$\mathrm{md}=\mathrm{man} / \mathrm{day} ;{ }^{1}$ as fed; ${ }^{2}$ Concentrate used per lactating cows; ${ }^{3}$ Concentrate used per all he herd; ${ }^{4} \mathrm{Without}$ payment of the land factor; ${ }^{5}$ With payment of the land factor. 
As the cows are culled after the end of the lactations, a smaller number of lactating cows implies a smaller number of culled cows. Furthermore, as the maximum number of lactations was established as six, all the cows that were not culled in previous lactations were sold after the sixth lactation number. This means that an increase in the calving interval implies increase in the average permanence time of the cows in the herd and a consequently decrease in the cow culled rate.

The use of labor decreased with the increase in calving interval, because of the decrease in the number of lactating cows and the total number of animals that are associated to the man-day of the milker and the temporary workers, respectively.

As expected, the increase in the calving interval caused reductions in milk gross income and total gross income. The percentage of milk gross income in the total gross income, however, was not altered, because the number of heifers and cows culled changed in the same proportion as the quantity of milk sold. In the production cost submodel, most of the effective operational cost components is associated to the number of lactating cows or with the total number of animals. Since both the number of lactating cows and the total number of animals decreased with the increase in CI, it was expected that the effective operational cost would perform similarly, which in fact it did. However, the effective operational cost of milk increased in response to increase in CI because of the fall in milk production. The total operational cost and the total production cost followed the same tendency as effective operational cost while the total operational cost of milk and total production cost of milk performed as the effective operational cost of milk, which was expected, due to the fixed character of family labor, depreciations and capital invested in installations, machines, and land.

The addition of one month in the calving interval corresponded, on average, to a decrease of approximately $\mathrm{R} \$ 16,230,00$ in the annual income of the company and the CIs of 15 and 16 months produced annual losses, with a return on capital invested in the activity but at rates lower than market interest.

The correlation was significant $(\mathrm{P}<0.01)$ between the values generated by the model and those observed in the company records, for all the variables assessed (Figure 5). The coefficients of correlation for total_number_of_animals (Figure 5a), total_number_of_cows (Figure 5b) and number_of_lactating_cows (Figure 5c) demonstrate that there was a high degree of linear association among the values.

For the daily_milk_production variable (Figure 5d), the coefficient of correlation was smaller than the others due to variations observed in the average milk yield per cow. The av erage daily milk yield per lactating cow that was between 20.7 and $24.7 \mathrm{~L}$ from January to August 2007 rose
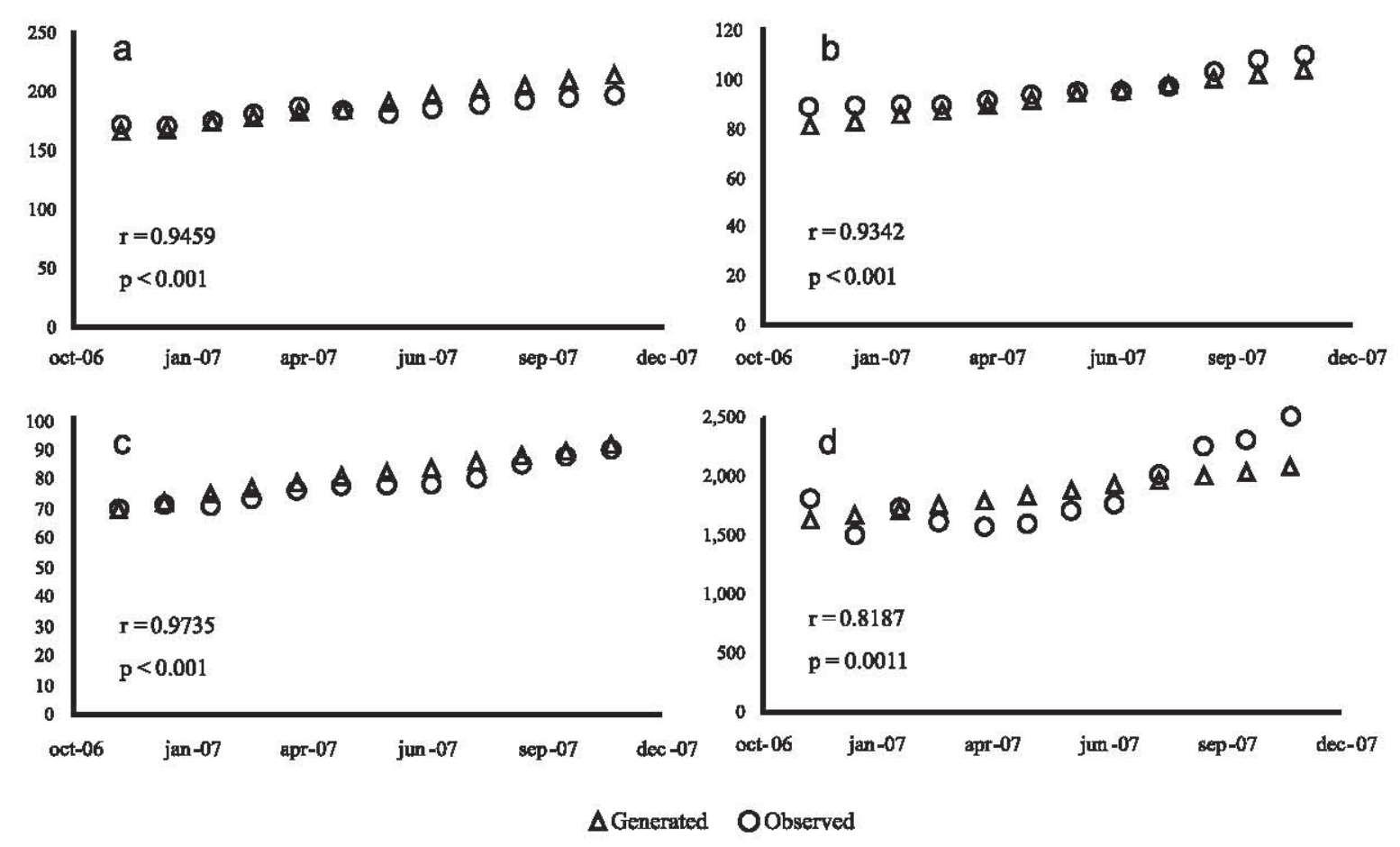

Figure 5 - Linear association among the values total_number_of_animals (a), total_number_of_cows (b),number_of_lactating_cows (c) and daily_milk_production (d) generated by the model and observed in the records of the production unit used from December 2006 to November 2007. 
to $26.5,26.2$ and $27.6 \mathrm{~L}$ in the months of September, October and December, respectively. A probable cause of the increase in yield observed after September 2007 was the use of bovine somatotropin, because the cost records of the farm showed that after this month, the company purchased hormones monthly. In the future, it will be possible to add this effect to the simulation model, so that the generated values can be closer to those observed.

\section{Conclusions}

The sensitivity analyses proves that the values produced by the simulation model performs as expected for the changes in the area used for corn crop for silage production and the calving interval. There is a relationship between the values generated by the simulation model and those observed in practice and the degree of association can be considered high for the total number of animals and total number of cows and number of lactating cows.

\section{References}

ÁVILA, W.R.B. Uso da dinâmica de sistemas como suporte à decisão em propriedades produtoras de leite: um estudo de caso. 2004. 127f. Dissertação (Mestrados em Economia Aplicada) - Universidade Federal de Viçosa, Viçosa, MG.

BARBOSA, W.V. Tempos pós-modernos. In: LYOTARD, J.F. (Ed.) O pós-moderno. Rio de Janeiro: J. Olimpio, 1986. p.7-18.

BERNARD, J.K.; WEST, J.W.; TRAMMELL, D.S., Effect of replacing corn silage with annual ryegrass silage on nutrient digestibility, intake, and milk yield for lactating dairy cows. Journal of Dairy Science, v.85, p.2277-2282, 2002.

BROCKINGTON, N.R. Curso de modelos de simulação. Juiz de Fora: Embrapa CNPGL, 1995. v.1, 238p.

CUNHA, D.N.F.V.; PEREIRA, J.C.; SILVA, F.F. et al. Selection of models of lactation curves to use in milk production simulation systems. Revista Brasileira de Zootecnia, v.39, n.4, p.891-902, 2010 .

DIJKSTRA, J.; FRANCE, J.; DHANOA. M.S. et al. A model describe growth patterns of the mammary gland during pregnancy and lactation. Journal of Dairy Science, v. 80 , p.2340-2354, 1997.
GAVARIA, M.O. Simulação computacional como ferramenta de aquisição de conhecimento. 2003. 163f. Dissertação (Mestrado em Engenharia de Produção) Escola de Engenharia de São Carlos/Universidade de São Paulo, São Carlos.

GOMES, S.T. Custo de produzir leite. In: __- Economia da produção do leite. Belo Horizonte: Itambé, 2000. p.41-42.

GUIMARÃES, V.P. Modelagem de uma unidade de produção para caprinos leiteiros utilizando a dinâmica de sistemas. 2007. 182f. Tese (Doutorado em Zootecnia) Universidade Federal de Viçosa, Viçosa, MG.

HIGH PERFORMANCE SYSTEMS, INC. STELLA. An introduction to systems thinking. New Hampshire: High Performance Systems, 2001. 165p.

LOPEZ, S.; FRANCE, J.; GERRITS, W.J.J. et al. A generalized Michaelis Menten equation for the analysis of growth. Journal Animal Science, v.78, p.1816-1828, 2004.

NATIONAL RESEARCH COUNCIL - NRC. Nutrient requirements of dairy cattle. Washington, D.C.: National Academy of Sciences, 2001. 363p.

OLIVEIRA, T.B.A.; FIGUEIREDO, R.S.; OLIVEIRA, M.W. et al. Índices técnicos de rentabilidade da pecuária leiteira. Scientia Agrícola, v.58, n.4, p.687-692, 1999.

OLIVEIRA, A.S.; CUNHA, D.N.F.V.; LEITE, S. et al. Identificação e quantificação de indicadores-referência de sistemas de produção de leite. Revista Brasileira de Zootecnia, v.36, n.2, p.507-516, 2007.

RENNÓ, F.P.; PEREIRA, J.C.; LEITE, C.A.M. et al. Eficiência bioeconômica de estratégias de alimentação em sistemas de produção de leite. 1. Produção por animal e por área. Revista Brasileira de Zootecnia, v.37, n.4, p.743-753, 2008a.

RENNÓ, F.P.; PEREIRA, J.C.; LEITE, C.A.M. et al. Avaliação bioeconômica de estratégias de alimentação em sistemas de produção de leite. 2. Metodologia alternativa: nível de utilização de capital. Revista Brasileira de Zootecnia, v.37, n. 4 , p.754-764, 2008 b.

RENNÓ, F.P.; PEREIRA, J.C.; LEITE, C.A.M. et al. Eficiência bioeconômica de vacas de diferentes níveis de produção de leite por lactação e estratégias de alimentação. Revista Brasileira de Zootecnia, v.37, n.4, p.765-772, 2008c.

RIBAS, N.P.; HARTMANN, W.; MONATES, H.D. et al. Sólidos totais no leite em amostras de tanque nos estados do Paraná, Santa Catarina e São Paulo. Revista Brasileira de Zootecnia, v.33, n.6, p.2343-2350, 2004.

ROTZ, C.A.; MERTENS, D.R.; BUCKMASTER, D.R. et al. A dairy herd model for use in whole farm simulations. Journal of Dairy Science, v.82, p.2826-2840, 1999.

TAYLOR, C.C.; ALLEN, M.S. Corn grain endosperm type and brown Midrib 3 corn silage: feeding behavior and milk yield of lactating cows. Journal of Dairy Science, v.88, p.1425-1433, 2005 . 